FORMATIONS OF BELIEF 


\section{PUBLICATIONS IN PARTNERSHIP WITH \\ THE SHELBY CULLOM DAVIS CENTER}

\section{AT PRINCETON UNIVERSITY}

The Spaces of the Modern City: Imaginaries, Politics, and Everyday Life, edited by Gyan Prakash and Kevin M. Kruse

Noir Urbanisms: Dystopic Images of the Modern City, edited by Gyan Prakash

Facing Fear: The History of an Emotion in Global Perspective, edited by Michael Laffan and Max Weiss

Cultures in Motion, edited by Daniel T. Rodgers, Bhavani Raman, and Helmut Reimitz

Formations of Belief: Historical Approaches to Religion and the Secular, edited by Philip Nord, Katja Guenther, and Max Weiss 


\title{
Formations of Belief
}

\author{
HISTORICAL APPROACHES \\ TO RELIGION AND THE SECULAR
}

\author{
EDITED BY \\ PHILIP NORD, KATJA GUENTHER, \\ \&ै MAX WEISS
}


Copyright (C) 2019 by Princeton University Press

Published by Princeton University Press

41 William Street, Princeton, New Jersey o8540

6 Oxford Street, Woodstock, Oxfordshire OX20 1TR

press.princeton.edu

All Rights Reserved

ISBN 978-0-691-19075-4

British Library Cataloging-in-Publication Data is available

Editorial: Eric Crahan \& Pamela Weidman

Production Editorial: Ali Parrington

Jacket Design: Layla Mac Rory

Jacket/Cover Credit: Rembrandt Harmensz van Rijn (1606-1669).

Jacob Wrestling with the Angel, ca. 1659-1660. Oil on canvas, $140.1 \times 120.0 \mathrm{~cm}$.

Inv. 828. Gemaeldegalerie, Staatliche Museen, Berlin. Photo: Christoph Schmidt /

Art Resource, NY

Production: Merli Guerra

Publicity: Alyssa Sanford \& Julia Hall

This book has been composed in Arno Pro

Printed on acid-free paper. $\infty$

Printed in the United States of America

1098766543321 